\title{
Approaching tobacco dependence in youngsters: impact of an interactive smoking cessation program in a population of Romanian adolescents
}

\author{
Gençlerde tütün bă̆ımlılı̆̆ına yaklaşım: Bir grup Romanyalı adolesanda \\ etkileşimli sigara bıraktırma programı
}

\author{
Antigona Trofor ${ }^{1}$, Stefan Mihaicuta ${ }^{2}$, Milena Adina Man ${ }^{3}$, Ramona Miron ${ }^{4}$, Valentina Esanu ${ }^{5}$, Letitia Trofor ${ }^{1}$ \\ ${ }^{1}$ University of Medicine and Pharmacy "Gr. T. Popa” Iasi, Romania \\ ¿University of Medicine and Pharmacy" Victor Babes" Timisoara, Romania \\ "University of Medicine and Pharmacy“Iuliu Hatieganu" Cluj, Romania \\ ${ }^{4}$ Clinic of Pulmonary Diseases, Iasi, Romania
}

\begin{abstract}
Objectives: The main objective of this study was to investigate the effectiveness of an interactive smoking cessation program when first implemented in a naïve population of Romanian adolescents. The secondary objective was to assess youngsters' attitudes and beliefs towards tobacco dependence, their compliance to smoking cessation interventions and success rate of a standard smoking cessation pilot program.
\end{abstract}

Materials and methods: A total of 231 subjects 14-19 years old participated in the Adolescent Smoking Cessation (ASC) pilot program in Romania in 2005. Subjects were evaluated based on the ASC questionnaire, a validated set of questions about smoking and cessation profile, whether current smoker or not. Smoking status was validated by carbon monoxide determination in exhaled air. Participants were delivered 6 interactive ASC sessions about smoking hazards and methods to quit smoking. A final evaluation was done to assess overall program's impact and to reward quitters and reducers by prizes.

Results: Study population was made of $52.4 \%$ every day smokers, $10.4 \%$ at least once/week but not every day smokers, $6 \%$ less than once/week smokers, $23.4 \%$ never smokers and $7.8 \%$ ex-smokers. Cessation rate was $12.3 \%$ in every day smokers and $16.6 \%$ in at least once a week but not every day smokers. Also, $4.1 \%$ every day smokers and $30 \%$ at least once/week not every day smokers reduced number of cigarettes smoked/day. The program registered a high attendance rate/sessions as $85.2 \%$ of subjects were present in all sessions. Also, significant changes occurred in participant's beliefs about smoking and cessation.

Conclusions: Pilot ASC was an efficient program with $12.3 \%$ of daily smokers to quit smoking and its positive impact on personal smoking and cessation beliefs in $90 \%$ of participants. J Clin Exp Invest 2010; 1(3): 150-155

Key words: smokers, smoking cessation, adolescents, peers, pilot project

\section{ÖZET}

Amaç: Bu çalışmanın ana amacı bir grup Romen adolesanda, ilk defa uygulandığında, interaktif bir sigara bıraktırma programının etkinliğini araştırmaktır. Çalışmanın ikincil amacı ise gençlerin sigara bağımlılığına, sigara bırakma girişimlerine ve standart sigara bırakma pilot uygulamalarına karşı tavır ve inançlarını değerlendirmektir.

Gereç ve yöntem: Romanya'da 2005 yılında, yaşları 1419 arasında değişen toplam 231 kişi Adolesan Sigara Bırakma (ASB) programına katıldı. Katılımcıların güncel içici olup olmadıkları, sigara içme ve bırakma profiline göre teyid edilmiş soru seti içeren ASB anketine dayanarak belirlendi. Sigara içme durumu, ekspiryum havasında karbon monoksit aranmasıyla araştırıldı. Katılımcılarla birlikte sigara içmenin zararları ve sigaradan kurtulma metotları hakkında 6 interaktif oturum gerçekleştirildi. Sonuç değerlendirmesi, programın genel etkinliğini değerlendirme ve sigarayı bırakan ya da azaltanları ödüllendirme ile yapıldı.

Bulgular: Çalışma grubunun \%52.4'ü her gün sigara içen, \%10.4'ü her gün sigara içmeyen ancak en az haftada bir sigara içen, \%6'sı haftada birden az içen, \%23.4'ü hiç sigara içmeyen ve \%7.8'i eskiden sigara içen bireyler içermekte idi. Sigara bırakma oranı, her gün sigara içenlerde \%12.3, her gün içmeyip haftada en az bir kez içenlerde \%16.6 idi. Ayrıca her gün sigara içenlerin \%4.1'i ile haftada en az bir kez içenlerin \%30'unda günlük içtikleri sigara sayısında azalma saptandı. Program bireylerin \%85.2'sinin tüm toplantılarda hazır bulunması ile yüksek bir katılım oranı sağladı. Ayrıca sigara içme ve bırakma ile ilgili katılımcıların inançlarında önemli değişiklikler oldu.

Sonuç: Pilot ASB programı, her gün sigara içenlerin \%12.3'ünün sigarayı bıraktığı etkili bir program idi ve katılımcıların \%90'ının sigara içme ve sigara bırakma konusundaki kişisel inançları üzerinde pozitif etkisi oldu. Klin Den Ar Derg 2010; 1(3): 150-155

Anahtar kelimeler: Sigara içicileri, sigarayı bırakma, adolesanlar, akranlar, pilot proje 


\section{INTRODUCTION}

Although most people are aware about deleterious effects of smoking over $30 \%$ of the world's population is made of smokers. Nicotine, an alkaloid component of tobacco that has addictive capacities is a psycho-active substance acting especially through reward (satisfaction) and memory systems.

Nicotine introduced in the body by smoking has the capacity to bind to specific nicotinic acetylcholine receptors found both in the central and peripheral nervous system. Thus, nicotine binding leads to opened ion channels (nicotinic receptors are ligand-gated to), allowing depolarisation and release of neurotransmitters, particularly dopamine., ${ }^{1,2}$ The intensity of nicotine dependence is very high, by comparison to other illicit drugs. On a progressive dependence scale from 5 to 1 , nicotine dependence is scored to 1 , heroine 2 , cocaine 3 , alcohol 4 and caffeine 5 . Therefore, defined as a chronic addictive disease, chronic tobacco consumption or simply "smoking" has been recognized by psychologists as a disease by itself, inducing physical, psychological and behavioral disorders. This disease is named "tobacco dependence" or "nicotine dependence" and it is caused by dependence to nicotine, a highly addictive drug present in any tobacco product. ${ }^{3}$ Moreover, in long term continuing smokers, chronic tobacco exposure has been proved to develop a wide variety of diseases, due to the numerous toxic compounds in tobacco.

\section{Problem formulation}

Statistics show high prevalence of smoking among young people. According to CDC data in $2005,{ }^{4}$ $23 \%$ of high school students report smoking in the last month, compared to $21.3 \%$ in 2003 and $36.4 \%$ in 1997. The prevalence of any form of tobacco use among 14-18 years old students in US was $28 \%{ }^{5}$ In Romania, ESPAD study in 1999 showed 21\% of Romanians over 15 to be daily smokers ${ }^{6}$ and $34.8 \%$ of young people 15-24 years old were found current smokers. $^{7}$

Among the 5 millions Romanians to smoke, more than half began smoking before the age of 18 . From these ones: $10.5 \%$ began in gymnasium (1114 yrs old), $36.9 \%$ in high school (15-18 yrs old) and $37.7 \%$ when $19-24$ years old. ${ }^{7}$ Also, cumulative probability to initiate smoking under 15 has in- creased between 2003-2007 from $4 \%$ to $12.8 \%$ in girls and from $19 \%$ to $20.2 \%$ in boys. ${ }^{8}$

Several approaches have been used to approach adolescents: programs to prevent smoking initiation, developing intrapersonal and social competencies to avoid smoking in vulnerable circumstances like peer smoking, developing skills to resist social pressure to smoke. The most efficient programs are multi componential interventions to combine school based and local society interventions. ${ }^{9}$

In Romania, standard interactive smoking cessation interventions targeting adolescents became available only in 2005 by "Adolescent smoking cessation" (ASC), a program designed by the Welsh Government Assembly in collaboration with ENYPAT (European Network for Young People and Tobacco) experts. ASC was successfully delivered in several European countries (United Kingdom, Sweden, Belgium, Spain, Greece, and Denmark) for the first time in 2004. In Romania, it was implemented in pilot phase in 2005, from behalf of the Nongovernmental association "Aer Pur Romania" when it was run in two cities: Iasi and Timisoara.

\section{AIM}

ASC program's primary objective was to provide smoking cessation to smoking adolescents. The secondary objective of ASC was to raise awareness of both no smokers and smokers' adolescents against tobacco use hazards and to promote a smoke free life style inside high school communities. This was done by assessing youngsters' attitudes and beliefs towards tobacco dependence, compliance to smoking cessation interventions and success rate of a standard smoking cessation program, when first implemented in a naive population of Romanian adolescents.

\section{PARTICIPANTS AND METHODS}

The study was carried out on 231 subjects that participated in (ASC) program, in its pilot phase in Romania, in 2005. Prior to beginning the project's sessions, program coordinators have contacted schools principals, to advertise ASC and to invite schools to take part to it. In a second phase, schools included in ASC had to inform teachers, students and parents about the program and to form mixed (smokers, ex smokers and no smokers altogether) groups of adolescents willing to be in ASC. 
Subjects were recruited and evaluated based on the ASC questionnaire, a validated set of questions about personal data, smoking and cessation profile, willingness to involve in ASC whether current smoker or not. Smoking status (current, former or no smoker) was validated at inclusion on basis of carbon monoxide determination in exhaled air.

To preview nicotine dependence profile in adolescents, we applied a set of 3 questions ("would you like to give up smoking?", "if smoker, do you find difficult to stop smoking when willing to?", "did you ever try to stop smoking?"). ${ }^{10}$

\section{ASC program description}

Along 3 months, study population was delivered 6 interactive ASC sessions. In the first session, ASC questionnaire was collected and smoking status was checked by carbon monoxide measurement in exhaled air. Also, subjects were explained what the program will consist of and the health benefits of quitting smoking. Interactivity between smokers, no smokers and facilitators was encouraged and the final $\left(6^{\text {th }}\right)$ session with prizes to reward quitting smoking was advertised. In sessions 2-5, students were given information on: different types of tobacco products and noxious tobacco components, dependence to nicotine in tobacco, active and passive smoking related diseases, smoking risk to pregnancy and motherhood, benefits of stopping smoking and methods to quit smoking. This was done in an interactive manner, with video-lessons and role-playing scenario. Such approach aimed to induce cigarette refusal skills and self esteem capacities in order to resist temptation to smoke in challenging situations as school or leisure time environment.

The $6^{\text {th }}$ session was dedicated to a final evaluation, as impact of ASC participation. Again, smoking status (smoking abstinence validated by carbon monoxide in exhaled air) and adolescents' beliefs towards smoking \& cessation were assessed by the ASC questionnaire distributed for the second time at the end of the program. Also, in this final session, participants that were found quitters and reducers were rewarded by prizes.

During all 6 sessions, children received small incentives, snacks and refreshments to stimulate participation and, where possible, a festive session (smoke-free disco) was organized as a practical lesson to test adolescents' readiness to stay smoke free.
Follow-up of participation rates / session was done in order to assess compliance to ASC. Success rate of the ASC program was appreciated by: a) primary outcomes (quitters and reducers ratio at the end of the program), b) secondary outcomes (compliance into ASC reflected in participation rate/session and impact of ASC on personal beliefs about smoking and cessation). In interpretation of results, special consideration was given to the initial level of knowledge /acceptability of smoking and to predicted nicotine dependence, as impact factors on program outcomes.

\section{RESULTS}

Eight high schools (4000 pupils in $9-12^{\text {th }}$ grade) were invited to subscribe ASC. Study inclusion criteria were: parents and teachers agreement letter, scholar agenda and facilities, pupils 'consent to take part in ASC, carbon monoxide validation test, ASC sessions participation rate $>66 \%$. Thus, 231 adolescents 14-19 years old were selected to be enrolled in the ASC project. Study population characteristics at inclusion were defined by ASC questionnaire, which provided data about: gender and age distribution, smoking profile and cessation profile. $57.1 \%$ of study population were girls and $42.9 \%$ boys.

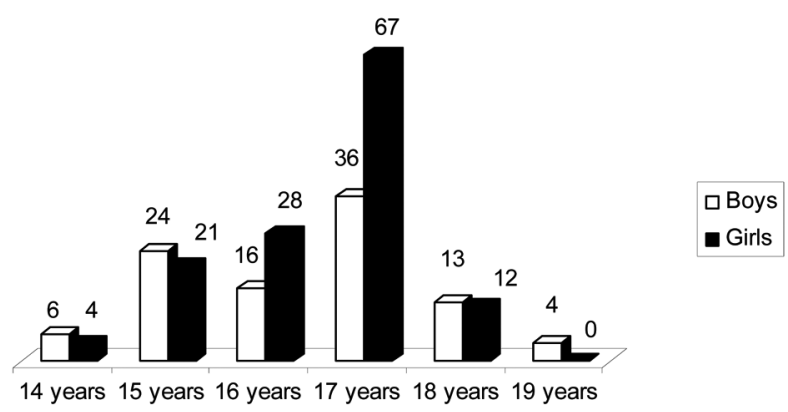

Figure 1. ASC study group distribution by age

As shown in Figure 1, girls and boys were almost equally represented in the study population and the same when compared by age, except 17 years old teenagers where girls were much more numerous.

\section{Smoking profile}

Smoking status defined by the five categories: every day smokers, at least once a week but not every day smokers, less than once a week smokers, used to smoke - actually stopped smoking and never smokers, with dynamics of these categories during the 6 weeks ASC project is shown in Figure 2. This al- 
lows calculation of quitters and reducers rates, as the program's primary goal was to determine adolescents to decline smoking.

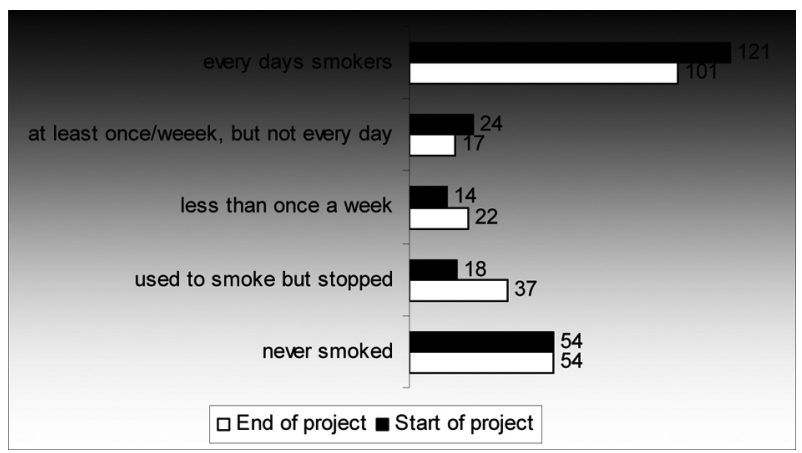

Figure 2. Smoking status dynamics during ASC program

Cessation rate was $12.3 \%$ (15 among 121) in every day smokers and $16.6 \%$ (4 among 24 ) in at least once a week but not every day smokers. Also, $5(4.1 \%)$ every day smokers and $8(30 \%)$ at least once/week, not every day smokers reduced cigarettes.

Other smoking characteristics, considered useful in data interpretation are listed bellow:

1. Intensity of cigarette consumption ranged between 8 - 40 cigarettes/ day in every day smokers and from 2 to 10 cigarettes in at least once/week but not every day smokers. Less than once a week smokers were mostly occasional experimenters to smoke at parties, in weekends and leisure time, between 1-5 cigarettes/month. Former smokers were not exceeding 10 cigarettes/ day in the past, when they used to smoke.

2. Duration of smoking ranged between: 4 months -3 years in every day smokers, 6-12 months in at least once/week but not every day smokers, 4-15 months in less than once a week smokers and 12 - 30 months in ex smokers.

3. Mean age of starting smoking was 12.6 years in every day smokers, 13.2 years in at least once/ week but not every day smokers and 14 years in less than once a week smokers.

4. Indices to predict nicotine dependence in smoking adolescents: among every day smokers we found $37.2 \%$ to answer positively to all 3 questions in item III of the ASC questionnaire. Only 5 such smokers succeeded to quit.

Personal beliefs about smoking were evaluated both at the beginning and at the end of ASC sessions and the overall picture can be seen in Table 1 .

Table 1. Personal beliefs about smoking at start (S) and end (E) of ASC. Response to question: "How far do you agree or disagree with these statements about smoking?"

\begin{tabular}{|c|c|c|c|c|c|c|c|c|c|c|}
\hline & \multicolumn{2}{|c|}{ Strongly disagree } & \multicolumn{2}{|l|}{ Disagree } & \multicolumn{2}{|l|}{ Not sure } & \multicolumn{2}{|l|}{ Agree } & \multicolumn{2}{|c|}{ Strongly agree } \\
\hline & $\mathrm{S}$ & $E$ & $S$ & $E$ & $S$ & $E$ & S & $E$ & $S$ & $E$ \\
\hline Young people who smoke harm their health & $\begin{array}{l}22 \\
(9.5 \%)\end{array}$ & $\begin{array}{l}4 \\
(1.7 \%)\end{array}$ & $\begin{array}{l}31 \\
(13.4 \%)\end{array}$ & $\begin{array}{l}6 \\
(2.6 \%)\end{array}$ & $\begin{array}{l}16 \\
(6.9 \%)\end{array}$ & $\begin{array}{l}0 \\
(0 \%)\end{array}$ & $\begin{array}{l}68 \\
(29.4 \%)\end{array}$ & $\begin{array}{l}104 \\
(45 \%)\end{array}$ & $\begin{array}{l}94 \\
(40.8 \%)\end{array}$ & $\begin{array}{l}117 \\
(50.7 \%)\end{array}$ \\
\hline Smoking increases your risk of heart attack & $\begin{array}{l}20 \\
(8.7 \%)\end{array}$ & $\begin{array}{l}11 \\
(4.8 \%)\end{array}$ & $\begin{array}{l}34 \\
(14.7 \%)\end{array}$ & $\begin{array}{l}20 \\
(8.7 \%)\end{array}$ & $\begin{array}{l}19 \\
(8.2 \%)\end{array}$ & $\begin{array}{l}0 \\
(0 \%)\end{array}$ & $\begin{array}{l}77 \\
(33.4 \%)\end{array}$ & $\begin{array}{l}60 \\
(26 \%)\end{array}$ & $\begin{array}{l}81 \\
(35 \%)\end{array}$ & $\begin{array}{l}140 \\
(60.5 \%)\end{array}$ \\
\hline Smoking increases your risk of getting cancer & $\begin{array}{l}20 \\
(8.7 \%)\end{array}$ & $\begin{array}{l}2 \\
(1 \%)\end{array}$ & $\begin{array}{l}35 \\
(15.2 \%)\end{array}$ & $\begin{array}{l}3 \\
(1.2 \%)\end{array}$ & $\begin{array}{l}19 \\
(8.2 \%)\end{array}$ & $\begin{array}{l}0 \\
(0 \%)\end{array}$ & $\begin{array}{l}76 \\
(32.9 \%)\end{array}$ & $\begin{array}{l}97 \\
(42 \%)\end{array}$ & $\begin{array}{l}81 \\
(35 \%)\end{array}$ & $\begin{array}{l}129 \\
(55.8 \%)\end{array}$ \\
\hline Smoking makes you feel grown up & $\begin{array}{l}56 \\
(24.2 \%)\end{array}$ & $\begin{array}{l}81 \\
(35 \%)\end{array}$ & $\begin{array}{l}34 \\
(14.7 \%)\end{array}$ & $\begin{array}{l}72 \\
(31.2 \%)\end{array}$ & $\begin{array}{l}8 \\
(3.5 \%)\end{array}$ & $\begin{array}{l}26 \\
(11.2 \%)\end{array}$ & $\begin{array}{l}55 \\
(23.8 \%)\end{array}$ & $\begin{array}{l}13 \\
(5.7 \%)\end{array}$ & $\begin{array}{l}78 \\
(33.8 \%)\end{array}$ & $\begin{array}{l}39 \\
(16.9 \%)\end{array}$ \\
\hline Smoking is harmful to others & $\begin{array}{l}80 \\
(34.6 \%)\end{array}$ & $\begin{array}{l}3 \\
(1.3 \%)\end{array}$ & $\begin{array}{l}67 \\
(29 \%)\end{array}$ & $\begin{array}{l}11 \\
(4.8 \%)\end{array}$ & $\begin{array}{l}12 \\
(5.2 \%)\end{array}$ & $\begin{array}{l}2 \\
(1 \%)\end{array}$ & $\begin{array}{l}11 \\
(4.8 \%)\end{array}$ & $\begin{array}{l}115 \\
(49.7 \%)\end{array}$ & $\begin{array}{l}61 \\
(26.4 \%)\end{array}$ & $\begin{array}{l}100 \\
(43.2 \%)\end{array}$ \\
\hline Smoking is expensive & $\begin{array}{l}74 \\
(32 \%)\end{array}$ & $\begin{array}{l}28 \\
(12.1 \%)\end{array}$ & $\begin{array}{l}56 \\
(24.3 \%)\end{array}$ & $\begin{array}{l}34 \\
(14.7 \%)\end{array}$ & $\begin{array}{l}23 \\
(10 \%)\end{array}$ & $\begin{array}{l}14 \\
(6.1 \%)\end{array}$ & $\begin{array}{l}34 \\
(14.7 \%)\end{array}$ & $\begin{array}{l}123 \\
(53.2)\end{array}$ & $\begin{array}{l}44 \\
(19 \%)\end{array}$ & $\begin{array}{l}32 \\
(13.9 \%)\end{array}$ \\
\hline Most young people smoke & $\begin{array}{l}18 \\
(7.8 \%)\end{array}$ & $\begin{array}{l}73 \\
(31.6 \%)\end{array}$ & $\begin{array}{l}24 \\
(10.4 \%)\end{array}$ & $\begin{array}{l}89 \\
(38.5 \%)\end{array}$ & $\begin{array}{l}18 \\
(7.8 \%)\end{array}$ & $\begin{array}{l}4 \\
(1.7 \%)\end{array}$ & $\begin{array}{l}92 \\
(39.8 \%)\end{array}$ & $\begin{array}{l}54 \\
(23.4 \%)\end{array}$ & $\begin{array}{l}79 \\
(34.2 \%)\end{array}$ & $\begin{array}{l}11 \\
(4.8 \%)\end{array}$ \\
\hline I don't mind if my friend smoke & $\begin{array}{l}19 \\
(8.3 \%)\end{array}$ & $\begin{array}{l}90 \\
(39 \%)\end{array}$ & $\begin{array}{l}16 \\
(6.9 \%)\end{array}$ & $\begin{array}{l}98 \\
(42.4 \%)\end{array}$ & $\begin{array}{l}10 \\
(4.3 \%)\end{array}$ & $\begin{array}{l}3 \\
(1.3 \%)\end{array}$ & $\begin{array}{l}110 \\
(47.6 \%)\end{array}$ & $\begin{array}{l}18 \\
(7.8 \%)\end{array}$ & $\begin{array}{l}76 \\
(32.9 \%)\end{array}$ & $\begin{array}{l}22 \\
(9.5 \%)\end{array}$ \\
\hline Smoking helps you keep slim & $\begin{array}{l}23 \\
(10 \%)\end{array}$ & $\begin{array}{l}96 \\
(41.6 \%)\end{array}$ & $\begin{array}{l}22 \\
(9.6 \%)\end{array}$ & $\begin{array}{l}88 \\
(38 \%)\end{array}$ & $\begin{array}{l}56 \\
(24.2 \%)\end{array}$ & $\begin{array}{l}13 \\
(5.6 \%)\end{array}$ & $\begin{array}{l}62 \\
(26.8 \%)\end{array}$ & $\begin{array}{l}22 \\
(9.5 \%)\end{array}$ & $\begin{array}{l}68 \\
(29.4 \%)\end{array}$ & $\begin{array}{l}12 \\
(5.3 \%)\end{array}$ \\
\hline Most adults smoke & $\begin{array}{l}20 \\
(8.7 \%)\end{array}$ & $\begin{array}{l}68 \\
(29.4 \%)\end{array}$ & $\begin{array}{l}34 \\
(14.6 \%)\end{array}$ & $\begin{array}{l}85 \\
(36.8 \%)\end{array}$ & $\begin{array}{l}0 \\
(0 \%)\end{array}$ & $\begin{array}{l}6 \\
(2.6 \%)\end{array}$ & $\begin{array}{l}87 \\
(37.7 \%)\end{array}$ & $\begin{array}{l}35 \\
(15.2 \%)\end{array}$ & $\begin{array}{l}90 \\
(39 \%)\end{array}$ & $\begin{array}{l}37 \\
(16 \%)\end{array}$ \\
\hline
\end{tabular}




\section{Cessation profile}

Own beliefs and attitudes towards cessation were evaluated both at the start of ASC and at the end. In the final session, program's impact was appreciated also by a set of questions to preview future attitude of adolescents towards smoking. At the start of ASC, only 78 adolescents were very much motivated to quit smoking while 29 were less motivated and the rest of 42 not at all motivated. As regards personal beliefs about cessation, the following pattern was registered at project's start:

- If deciding to quit: 65 (43.6\%) subjects were very sure to be able to succeed, $47(31.5 \%)$ quite sure and 48 not at all sure.

- A high ratio (64.2\%) of smokers admitted they need professional help to quit smoking.

A second positive outcome of ASC was a high number of participants that have attempted to stop smoking for short time (one to several days) at least once, during the program. Thus, we have found the following data:
- $103(66.9 \%)$ subjects among 154 still smoking at the end of ASC have stopped smoking at any time during the project, even if only temporarily (36 once, 42 twice and 25 three times).

- The longest period they managed to stay smoke-free was more than 3 weeks, up to 4 weeks in 8 subjects.

To appreciate ASC 'impact on participants we reviewed their answers when asked about:

- To what extent did the program help them to quit/attempt quit/cut down? (77.8 \% answered "yes").

- How confident are you that you would not be smoking cigarettes this time next year? This question was focusing on those that had attempted to quit and were still stopped at the end of the project (12 subjects answered ,very confident”, 6 as „fairly confident”, while just one as ,non confident”)

- By the end of the program, how aware are you about smoking cessation and where to go for support? (Table 2, for answers).

Table 2. How aware were participants about smoking cessation at the end of the ASC program?

\begin{tabular}{|c|c|c|c|c|c|}
\hline & $\begin{array}{l}\text { Strongly } \\
\text { disagree } \\
n(\%)\end{array}$ & $\begin{array}{l}\text { Disagree } \\
\mathrm{n}(\%)\end{array}$ & $\begin{array}{l}\text { Not sure } \\
\mathrm{n}(\%)\end{array}$ & $\begin{array}{l}\text { Agree } \\
\mathrm{n}(\%)\end{array}$ & $\begin{array}{l}\text { Strongly } \\
\text { agree } \\
\mathrm{n}(\%)\end{array}$ \\
\hline I now have better understanding of how to quit smoking & $\begin{array}{l}8 \\
(3.5 \%)\end{array}$ & $\begin{array}{l}6 \\
(2.6 \%)\end{array}$ & $\begin{array}{l}3 \\
(1.3 \%)\end{array}$ & $\begin{array}{l}97 \\
(42 \%)\end{array}$ & $\begin{array}{l}117 \\
(50.6 \%)\end{array}$ \\
\hline I now have better understanding about where to go for help about quitting & $\begin{array}{l}3 \\
(1.3 \%)\end{array}$ & $\begin{array}{l}6 \\
(2.7 \%)\end{array}$ & $\begin{array}{l}9 \\
(3.9 \%)\end{array}$ & $\begin{array}{l}132 \\
(57.1 \%)\end{array}$ & $\begin{array}{l}81 \\
(35 \%)\end{array}$ \\
\hline I now have better understanding of why it is important to quit smoking & $\begin{array}{l}2 \\
(0.8 \%)\end{array}$ & $\begin{array}{l}1 \\
(0.4 \%)\end{array}$ & $\begin{array}{l}0 \\
(0 \%)\end{array}$ & $\begin{array}{l}117 \\
(50.6 \%)\end{array}$ & $\begin{array}{l}111 \\
(48.2 \%)\end{array}$ \\
\hline I now have better understanding of the effects of smoking & $\begin{array}{l}3 \\
(1.3 \%)\end{array}$ & $\begin{array}{l}1 \\
(0.5 \%)\end{array}$ & $\begin{array}{l}2 \\
(1 \%)\end{array}$ & $\begin{array}{l}131 \\
(56.6 \%)\end{array}$ & $\begin{array}{l}94 \\
(40.6 \%)\end{array}$ \\
\hline
\end{tabular}

Another parameter useful to assess program's impact was compliance of participants, appreciated by participation rate/session, as in Figure 3. Here it is revealed the project benefited a high interest, with optimal attendance rate/sessions, over $85.2 \%$. Moreover, all participants in sessions 1 and 6 had carbon monoxide tests, for study data validation.

\section{DISCUSSION}

ASC results provide strong support for the efficacy of interactive smoking cessation programs in adoles- cents, particularly within a naïve population. Overview of literature in the field showed comparable 6.8 to $12.3 \%$ smoking cessation rate in young daily smokers of 1-9 to $>10$ cigarettes/day. ${ }^{11}$ Also, comparison between data in Romanian ASC and ASC in other European countries showed great variability: $14 \%$ quitters in Denmark, $9 \%$ in Slovakia, 0\% in Netherlands and 35\% in Wales (the ASC mother country). ${ }^{12}$

Pilot ASC results need to be analyzed within context of ASC study group structure (small sample 
of teenagers, being part of a pilot European project delivered by volunteers, low funding,) and weak legislation at the time (tobacco advertising and smoking in public places was still allowed in 2005). Yet, the program was very welcomed in Romania, especially when compared to other countries where ASC was delivered (and where only $57 \%$ of participants attended all sessions - ranging from $100 \%$ in Netherlands to $18 \%$ in Denmark). ${ }^{12}$ When questioned in the first session about hazards of smoking, subjects agreed smoking harms young people's health in $70.1 \%$, increases risk of heart attack and cancer in $68.4 \%$. By the end of ASC, perception about health risks of smoking changed: $95.7 \%$ agreed smoking' health risks, $86.6 \%$ were aware that smoking induces heart attack and $97.8 \%$ linked smoking to cancers. Acceptability of smoking decreased due to ASC from 80.5 to $17.3 \%$, as a good impact of the program. Similar analysis from a survey when subjects asked whether "smoking was OK for someone their age just to try to see how it is", revealed 38 $\%$ of pupils to answer "yes" in $2007 .{ }^{13}$ Immediate benefit of ASC was appreciated based on: high ratio $(66.9 \%)$ of attempts to stop smoking, majority of quitters to be confident in a successful quit attempt and perceived support given by ASC for quit attempts in $77.8 \%$.

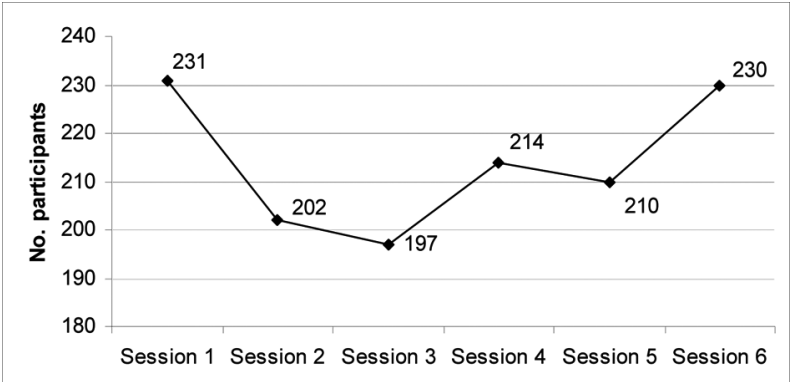

Figure 3. Participation rate / session

Better understanding (over 90\% in average) of how to quit smoking, where to go for help about quitting, why is it better to stop smoking and increased awareness about effects of smoking, as shown in table II allows optimistic estimates of the long term impact of the program. As it worked by peers, young facilitators, by putting together active and former smokers with never smokers, by interactive sessions, incentives and prizes, ASC provided insights into what works and what does not work in delivering smoking cessation in adolescents. ${ }^{14}$

\section{CONCLUSIONS}

ASC pilot project run in 2005 was the first expert smoking cessation program delivered to Romanian adolescents. $12.3 \%$ of every day smokers and $16.6 \%$ of at least once a week but not every day smokers succeeded to quit smoking. Impact of ASC program on smoking and cessation beliefs and attitudes was positive in $90 \%$ of participants. As Romanian ASC in 2005 was successful for both adolescents and facilitators, it became a national program run in 2007-2008 in partnership between Aer Pur Romania and Romanian Health Ministry. Lessons from ASC sustain recommendations to approach smoking cessation in teenagers by always asking about tobacco use, routinely advice to quit, provide accessible and appropriate therapy focusing on peers, incentives and interactivity and in respect to this age category smoking profile.

\section{REFERENCES}

1. Benowitz NL. Neurobiology of nicotine addiction: implications for smoking cessation treatment, Am J Med 2008; 121: S3S10.

2. Benowitz NL. Pharmacology of nicotine: addiction, smokinginduced disease and therapeutics, Ann. Rev Pharmacol Toxicol 2009; 49: 57-71.

3. Trofor A. et. al. Smoking cessation and smoker's assistance guidelines in Romania (GREFA), Tehnopress publisher House, Iasi, 2008, p. 21-25.

4. Teen Smoking Statistics, CDC, Mayo Clinic, ALA, Teen Help. com

5. Giovino G.A., The Tobacco Epidemic in the United States, Am Journal of Preventive Medicine 2007;33(6S):S318-S326.

6. Trofor A., Mihaltan F, Mihaicuta S., Lotrean L., Smoking cessation and prevention for young people- Romanian expertise, Pneumologia 2009;58:72-78

7. Romanian National Center for Health Politics and Services 2007 statistics

8. World No Tobacco Day data press release, 31-st of May, Bucharest, Romania, www.ms.ro

9. Tonnensen P. How to reduce smoking among teenagers, Eur Respir J 2002; 19:1-3.

10. Statistics on smoking: England 2008, report of National Statistics, The Information Center for Health and Social Care, 16 October 2008, p.53-60.

11. Sargent J.D.,Mott L.A., Stevens M., Predictors of smoking cessation in adolescents, Arch Pediatr adolesc Med 1998;152:38893.

12. Mac Donald S,Geesink I,Moore L. Evaluation of European Adolescent Smoking Cessation Pilot Programme Report for the Welsh Assembly Government, ISSN 1-904815-41-3.

13. General Household Survey 2006 Office for National Statistics, 2008. Available at: www.statistics.gov.uk/ghs/

14. Fiore MC, Jaén CR, Baker TB, et al. Treating Tobacco Use and Dependence: 2008 Update. Clinical Practice Guideline. Rockville, MD: U.S. Department of Health and Human Services. Public Health Service. May 2008.Learnings 